\section{The day we met Julian Tudor Hart}

One sunny April day in 2014 we knocked on the cottage door. We had arranged to see Julian Tudor Hart but his wife Mary told us he was not well. 'But wait a minute', she said.

'Yes', it was OK to come in. Julian was in pain from sciatica and rather fed up. However, he roused himself and within moments the conversation was flowing. As it then did over lunch and all afternoon.

He was then 87 and had spent most of his working life at Glyncorrwg Health Centre, in a former mining valley in South Wales. His leftwing lay deep and he stood unsuccessfully for parliament three times as a Communist Party candidate. Although personally charming, considerate, and hospitable, he still was fiercely opposed to politicians whom he thought were betraying ordinary people.

We ranged over his considerable research, the 'Inverse Care Law' being the prime example. By his life he showed that it was possible to combine daily practice with substantial academic work. In 2006, he was awarded the inaugural Discovery Prize by the RCGP as a general practitioner who has captured the imagination of generations of GPS with his groundbreaking research: He was respected by those who held very different views from his own, and in turn freely admitted learning from those who opposed him.

Retirement for Julian was clearly not inactivity and his passion never faltered as we talked. Inevitably the time to leave drew near and we admired the view over the Gower from his window. We broached the question of why the glorious creation we see can be evidence for a Divine Creator. And Julian, deeply convicted socialist that he was, surprised us by his answer. 'I am closer than you think.

Julian Tudor Hart had a vast influence on others personally, medically, politically, and academically. He showed us how fruitful a dedicated life can be, even a mere practising GP.

Greg Irving,

Clinical Lecturer in General Practice, University of Cambridge.

Email: gi226lacam.ac.uk
John Holden,

GP, Wigan.

Sadly John Holden died soon after writing this letter. His Appreciation can be found next to Julian Tudor Hart's on pages 432-433.

DOI: https://doi.org/10.3399/bjgp18X698501

\section{Clinical reflection: part of being a good doctor and a necessary ingredient for high- quality patient care, and lifelong learning}

I very much appreciate the article by Harris and colleges flagging up the topic of reflection in NHS appraisal and the negative experience and feedback on reflective writing. ${ }^{1}$ Reflective practice is an essential activity for healthcare professionals and should be an integral part of all aspects of healthcare delivery, as it aids the development of professionalism by facilitating lifelong learning and can reduce diagnostic errors. ${ }^{2}$ Reflective writing can help to process emotions, improve mood, prevent burnout, and improve the patient's care. ${ }^{3}$ Clinical reflection is not developed spontaneously and therefore is an essential part of the curriculum development. ${ }^{4}$

Unfortunately, despite being part of the undergraduate education, some students perceive reflective writing as irrelevant or even a nuisance or a waste of time. Reflection and reflective writing are clinical-relevant skills, and their practice can help with becoming a better physician. Clinical reflection shouldn't merely be reduced to a tick-box exercise, but progress to a powerful tool, which can be individualised by the user to connect up-todate learning and teaching methods. ${ }^{5}$ Further studies are needed in order to evaluate the effect of different educational strategies and supportive tools to promote its development and prevent reflection fatigue. ${ }^{6}$
Bernard Klemenz,

GP, University Surgery, Portsmouth.

Email: bernardlddoctors.org.uk

\section{REFERENCES}

1. Curtis P. Booth P. Frankland S, Harris M. Written reflection in NHS appraisal: time for an alternative. Br J Gen Pract 2018; DOI: https://doi.org/10.3399/ bjgp18X697601.

2. Gostelow N, Gishen F. Enabling honest reflection: a review. Clin Teach 2017; 14(6): 390-396.

3. Veno M, Silk H, Savageau JA, Sullivan KM. Evaluating one strategy for including reflection in medical education and practice. Fam Med 2016; 48(4): 300-304.

4. Academy of Medical Royal Colleges. Improving feedback and reflection to improve learning: a practical guide for trainees and trainers. London: AoMRC, 2017

5. Sandars J. The use of reflection in medical education: AMEE Guide No. 44. Med Teach 2009 31(8): 685-695

6. Mann K, Gordon J, MacLeod A. Reflection and reflective practice in health professions education: a systematic review. Adv Health Sci Educ Theory Pract 2009: 14(4): 595-621.

DOI: https://doi.org/10.3399/bjgp18X698465

\section{Management of exertional heat stroke}

I read with interest the article by Wallace and Steel regarding the management of exertional heat stroke from primary care physicians. ${ }^{1}$ Without question, improper management and care of an exertional heat stroke (EHS) patient can lead to increased risk of morbidity and mortality, thus necessitating the adoption and implementation of current standards of care for the recognition and management of EHS. ${ }^{2-4}$

With a focus on the primary care physician in this article, the authors discuss the onsite treatment of EHS (for example, during a mass participation event such as a road race) and subsequent care following the event. Within the section on EHS treatment, there are a few concerns that must be addressed. First, to reduce the risk of long-term morbidity or mortality related to EHS, the primary goal for EHS treatment is to reduce core body temperature below the critical threshold of cell damage $\left(>40.83^{\circ} \mathrm{C}\right)$ within 30 minutes 